\title{
Trastuzumab immunogenicity development in patients' sera and in laboratory animals
}

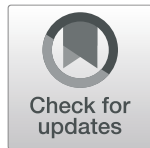

Lobna Abdel Aziz Kilany' ${ }^{1}$ Ayman Abdel Samie Gaber ${ }^{2}$, Mohammad Mabrouk Aboulwafa ${ }^{3,4^{*}}$ and Hamdallah Hafez Zedan ${ }^{5}$

\begin{abstract}
Background: Immunogenicity is a major challenge in drug development and patient care. Clinicians and regulators are familiar with immunogenicity concerns of monoclonal antibody (mAb) therapeutics, growth factors and enzyme replacements. Although most small therapeutic molecules are unlikely to trigger undesirable immunogenic responses against themselves upon their administration, the biological therapeutic agents are likely to induce such kind of immunogenicity. This imparts a problem that has to be considered upon judging their risk-benefit ratio. In this article, we tested the immunogenicity developed in patients' sera due to the use of trastuzumab and that developed in laboratory animals injected with this recombinant humanized lgG1 monoclonal antibody.

Methods: We studied trastuzumab immunogenicity by: I in vitro detection of anti-trastuzumab antibody (Ab) levels in patient's serum samples withdrawn at different points during trastuzumab treatment course; I.1 using an Affinity Capture Elution (ACE) assay, the assay is both sensitive and highly tolerant to free drug; I.2 using MTT cytotoxicity method against MCF-7 cell line as confirmatory method used in sample showed high level of anti-trastuzumab Ab and to determine neutralizing activity of the anti-trastuzumab Ab. II in vivo immunogenicity testing of trastuzumab in lab animals.
\end{abstract}

Results: In vitro analysis of patients' sera for antibodies developed against trastuzumab revealed that this monoclonal antibody has low immunogenicity since most samples showed low levels of anti-trastuzumab antibodies that decreased progressively along the treatment course. Only 1\% of samples showed high levels of anti-trastuzumab antibodies which might affect treatment course. In vivo immunogenicity testing in mice showed also low immunogenicity of trastuzumab that could support the in vitro clinical assessment applied in our study.

Conclusions: The study gives an evidence for the low trastuzumab immunogenicity when assessed in Egyptian patients under treatment with this biological therapeutic agent. This supports its prescription and continuous use across the approved indications as biological therapeutic agent.

Keywords: Trastuzumab, Immunogenicity, ELISA, ACE assay, Lab animals

\footnotetext{
* Correspondence: maboulwafa@yahoo.com;

maboulwafa@pharma.asu.edu.eg; mohammad.aboulwafa@ksiu.edu.eg

${ }^{3}$ Department of Microbiology and Immunology, Faculty of Pharmacy, Ain

Shams University, African union organization Street, Abbassia, Cairo 11566,

Egypt

${ }^{4}$ Faculty of Pharmacy, King Salman International University, Ras-Sedr, South

Sinai, Egypt

Full list of author information is available at the end of the article
}

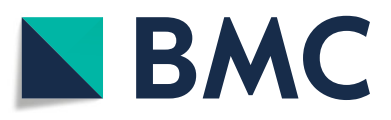

(c) The Author(s). 2021 Open Access This article is licensed under a Creative Commons Attribution 4.0 International License, which permits use, sharing, adaptation, distribution and reproduction in any medium or format, as long as you give appropriate credit to the original author(s) and the source, provide a link to the Creative Commons licence, and indicate if changes were made. The images or other third party material in this article are included in the article's Creative Commons licence, unless indicated otherwise in a credit line to the material. If material is not included in the article's Creative Commons licence and your intended use is not permitted by statutory regulation or exceeds the permitted use, you will need to obtain permission directly from the copyright holder. To view a copy of this licence, visit http://creativecommons.org/licenses/by/4.0/. The Creative Commons Public Domain Dedication waiver (http://creativecommons.org/publicdomain/zero/1.0/) applies to the data made available in this article, unless otherwise stated in a credit line to the data. 


\section{Background}

Immunogenicity is the undesired immune response due to the development of an adaptive immune response to a therapeutic agent [1-3]. Typically, this reaction occurs when foreignness or stress signals are perceived by the immune system, which triggers the humoral response by developing specific anti-drug antibodies (ADAs; also referred to as anti-therapeutic antibodies (ATAs)) to the therapeutic agent. Clinicians and regulators can't predict the clinical relevance of these ADAs as has ranged from no clinical relevance detected up to life-threatening responses [3].

A study for evaluation and reporting immunogenicity data, review the prescribing information and clinical review of Food and Drug Administration (FDA) for 121 approved biological products show that $89 \%$ of the products had reported immunogenic (IG), and $49 \%$ of the immunogenic products showed impact on its efficacy [4]. Biotherapeutic proteins are used to treat a wide variety of diseases, ranging from the rare (e.g., hemophilia) to the common (e.g., diabetes and cancer). An important safety and efficacy concern with biotherapeutic proteins is the risk of immunogenicity. For some biotherapeutics, the prevalence of ADAs in the patient population can be as high as $87 \%$ [5]. ADAs sometimes affect the biological function of the biotherapeutic, and these are called neutralizing ADAs (nADAs) or neutralizing antibodies (NABs). However, even antibodies that do not directly affect the function of the proteins (sometimes referred to as binding antibodies) can enhance, or impede, the clearance of the therapeutic agent, and thus affect a drug's pharmacokinetics (PK) and/or the pharmacodynamics (PD). Risks of immunogenicity can range from no clinical adverse effects to life threating adverse effects as ADA can impact both safety and bioavailability of the drug. In rare cases, immune responses can be severe, resulting in hypersensitivity reactions and even death [6]. The most common adverse reactions associated with trastuzumab products in the metastatic breast cancer setting are fever, nausea, vomiting, infusion reactions, diarrhea, infections, increased cough, headache, fatigue, dyspnea, rash, neutropenia, anemia, and myalgia [7]. In clinics, safety measures should be taken in case of immunogenic response detected; immunogenicity may require dose escalations, alternative treatments, frequent testing, and hospitalizations $[1,5]$. Anticancer chemotherapy involving trastuzumab should be administered only to patients for whom treatment with Herceptin is judged to be appropriate, at medical institutions where effective emergency treatment can be provided. The immunogenicity of many clinically approved products has been documented very well while some have failed even before reaching clinical trials. The development of ADA can affect efficacy and safety of the therapeutic proteins
[8]. Different factors may influence the immunogenicity of therapeutic proteins: structural features (variation of sequence and glycosylation), change in labelled storage conditions (cause denaturation or aggregation), if preparation contains any contaminants or impurities, duration and frequency of treatment, and route of administration; all of these factors or relevant factors elicit complex interactions between the patient's body and the biological drug [9]. Non-clinical immunogenicity assessments are very useful. They can be used to select candidate drugs in early stages of development $[8,10]$. In our study we used In vivo immunogenicity testing of trastuzumab in lab animals and the data obtained supported results of the in vitro assay for trastuzumab immunogenicity in patient's sera. There are two types of ADA formed, either persistent or transient, the latter type (transient ADA) is of less concern as it found rarely impact clinical outcomes and cause adverse events. Formation of ADA may occur immediately after initiation of $\mathrm{mAb}$ treatment course or later during treatment when reaching the concentrations that completely neutralize the drug. All regulators requirements include an accurate and reliable detection of ADA to $\mathrm{mAb}$ in clinical trials for ensuring safety of the drug and aids in understanding efficacy of mAb [11]. Trastuzumab (Herceptin ${ }^{\circ}$; Genentech, San Francisco, CA, USA) is a recombinant humanized monoclonal antibody IgG1 targeting human epidermal growth factor receptor-2 (HER2) and has substantially improved the prognosis of HER2positive breast cancer [12]. Administration of the intravenous (IV) formulation of trastuzumab that we used in our study can be either weekly infusions (initial dose of $4 \mathrm{mg} / \mathrm{kg}$ followed by subsequent doses of $2 \mathrm{mg} / \mathrm{kg}$ ) or every 3 weeks (initial dose of $8 \mathrm{mg} / \mathrm{kg}$ followed by subsequent doses of $6 \mathrm{mg} / \mathrm{kg}$ ) according to the label recommendation and depending on the indication the regimen chosen. For new drug approvals immunogenicity detection is required in clinical trials and can be detected by measurement of ADA in patients. Different assays can be used for immunogenicity detection of $m A b$, assays must be sensitive enough to detect low levels of ADA and be able to differentiate between the drug and the ADA, selecting an appropriate method is very important to reduce false results and clearly detect immunogenicity rates and severity [13-18]. Trastuzumab as a monoclonal antibody could induce the activation of a humoral immune response generating anti-drug antibodies (ADAs) which could block the action of trastuzumab and forming immune complexes which decrease its efficacy. Many studies measured trastuzumab immunogenicity, Hanna studied trastuzumab immunogenicity using highly sensitive assay and compared between different routes of administration (SC/IV formulation). ADA against both formulas of trastuzumab were detected 
transiently and were of no relevance in terms of efficacy and safety [18-22]. Clinical studies were conducted and immunogenicity of IV trastuzumab with biosimilar drugs was compared. The results reported that both trastuzumab and its biosimilar drugs showed markedly low ADA, that indicate low immunogenicity of trastuzumab. Furthermore, none of the patients included in the studies and who were ADA positive presented significant adverse events (AEs) related to immunogenicity or show a significant difference in efficacy and safety results [2327]. The present study focused on in vivo immunogenicity testing of trastuzumab in lab animals and in vitro detection of anti-trastuzumab antibody $(\mathrm{Ab})$ levels in Egyptian patients' serum samples withdrawn at different points during trastuzumab treatment course. The in vivo and in vitro analysis of trastuzumab immunogenicity revealed that it's of low immunogenicity among Egyptian patients and supports data for Herceptin (trastuzumab) which show that trastuzumab has low immunogenicity across all indications and its clinical continuous use as biologic therapeutic agent $[7,9,19,26,28]$.

\section{Results}

Table 1 shows a summary of immunogenicity testing that was conducted in laboratory animals and patients' sera and results obtained.

\section{In vivo immunogenicity testing of trastuzumab in lab animals}

Male Swiss albino mice were used for in vivo immunogenicity testing of trastuzumab using four groups of lab animals, each consisting of seven mice. At the end of the experiment, the remaining survived mice were five in case of control group, three in group I, three in group II and two in group III. Figure 1 shows the antibody titers developed in the pooled serum of each group. The results obtained revealed that the trastuzumab is of low immunogenicity in mice since the anti-trastuzumab $\mathrm{Ab}$

Table 1 Summary of immunogenicity testing of trastuzumab in laboratory animals and patients' sera

\begin{tabular}{|c|c|c|}
\hline $\begin{array}{l}\text { Applied } \\
\text { approach }\end{array}$ & \multicolumn{2}{|c|}{$\begin{array}{l}\text { (A) In vivo immunogenicity testing of trastuzumab in lab animals } \\
\text { (B) In vitro detection of anti-trastuzumab Ab levels in patient's serum samples }\end{array}$} \\
\hline \multirow[t]{8}{*}{ Methodology } & $\begin{array}{l}\text { Approach } \\
\text { A }\end{array}$ & Using one control group and 3 groups injected with different concentrations of trastuzumab. \\
\hline & \multirow{7}{*}{$\begin{array}{l}\text { Approach } \\
\text { B }\end{array}$} & Using ACE assay (analysis of serum samples of 101 patients) \\
\hline & & 1 Analysis of 18 patient's serum samples withdrawn before trastuzumab treatment course \\
\hline & & 2 Analysis of 46 patient's serum samples withdrawn at a single point during trastuzumab treatment course \\
\hline & & 3 Analysis of serum samples of 32 patients withdrawn at 2 different points during trastuzumab treatment course \\
\hline & & 4 Analysis of 5 patient's serum samples withdrawn after trastuzumab treatment course \\
\hline & & Using MTT cytotoxicity assay \\
\hline & & $\begin{array}{l}\text { Determination of neutralizing activity of anti-trastuzumab Ab in a single patient's serum sample that showed highest } \\
\text { ADA titer }\end{array}$ \\
\hline \multirow[t]{8}{*}{ Results } & $\begin{array}{l}\text { Approach } \\
\text { A }\end{array}$ & $\begin{array}{l}\text { Results are presented in Fig. } 1 \\
\text { - Trastuzumab showed low immunogenicity in mice since the anti-trastuzumab Ab levels developed in tested groups } \\
\text { injected with the drug didn't exceed } 1.3\end{array}$ \\
\hline & \multirow{7}{*}{$\begin{array}{l}\text { Approach } \\
\text { B }\end{array}$} & Using ACE assay (analysis of serum samples of 101 patients) \\
\hline & & $\begin{array}{l}1 \text { - Only } 3 \text { serum samples showed anti-trastuzumab Ab titers between 0.7-0.8 while the rest samples showed no de- } \\
\text { tected anti-trastuzumab Ab }\end{array}$ \\
\hline & & $\begin{array}{l}2 \text { Results are presented in Table } 2 \\
\text { - } 30 \text { samples showed no detected anti-trastuzumab Ab while the remaining } 16 \text { samples showed variable levels of } \\
\text { anti-trastuzumab Ab titers ranging from 1.07-8.18. }\end{array}$ \\
\hline & & $\begin{array}{l}3 \text { Results are presented in Table } 3 \\
\text { - at the 1st assay point } 16 \text { out of } 32 \text { tested samples showed variable levels of anti-trastuzumab Ab ranging from } 1.13- \\
\text { 4.64, while at the } 2 \text { nd assay point only } 9 \text { out of } 32 \text { tested samples showed variable levels of anti-trastuzumab Ab ran- } \\
\text { ging from 1.01-2.4 }\end{array}$ \\
\hline & & $\begin{array}{l}4 \text { Results are presented in Table } 4 \\
\text {-Only two serum samples coded T3-99 and T3-100 of two patients showed elevated levels of ADAs of } 103.63 \text { and } \\
\text { 7.13, respectively. The patient of the serum sample coded T3-99 didn't complete the } 17 \text { doses of trastuzumab } \\
\text { treatment course as she didn't respond clinically to treatment. She only received } 2 \text { doses of trastuzumab }\end{array}$ \\
\hline & & Using MTT cytotoxicity assay \\
\hline & & $\begin{array}{l}\text { Results are presented in Table } 5 \\
\text { - the neutralization of trastuzumab activity was observed when: } \\
\text { 1- the drug and serum preparations were added simultaneously to MCF-7 cell line } \\
\text { 2- the serum preparations were added to MCF-7 cell line one hour before drug addition }\end{array}$ \\
\hline
\end{tabular}




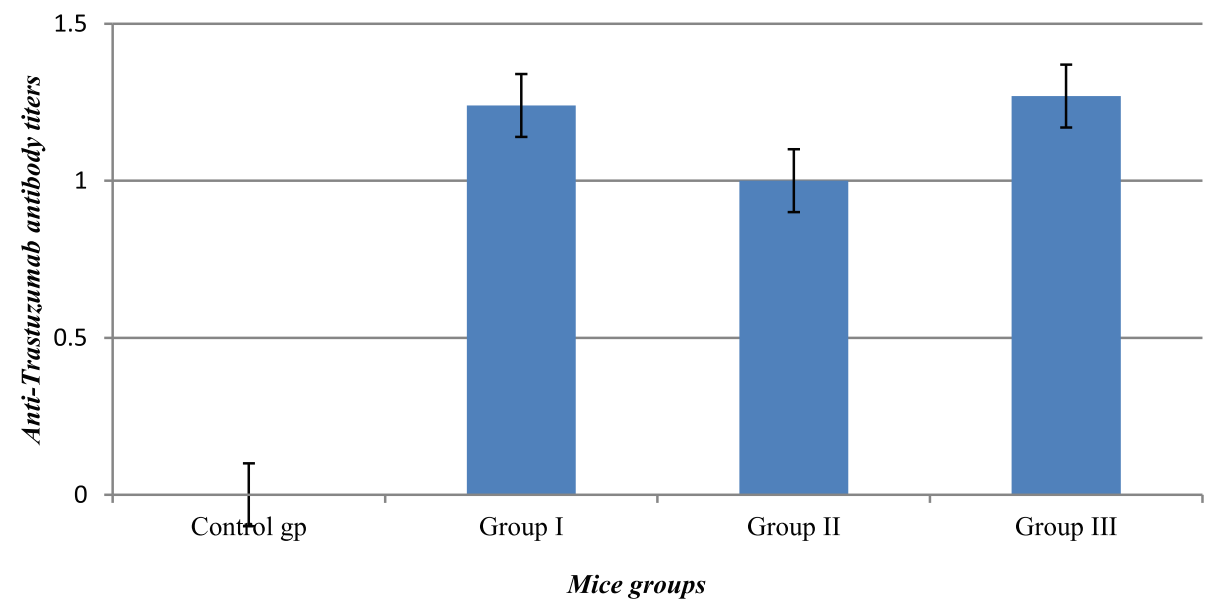

Fig. 1 Anti-trastuzumab antibody levels developed in mice injected with different concentrations of trastuzumab. Control group, mice injected with only normal saline; group I, mice injected with $14.8 \mathrm{mg}$ trastuzumab/kg body weight; group II, mice injected with $74 \mathrm{mg}$ trastuzumab/kg body weight; group III, mice injected with $148 \mathrm{mg}$ trastuzumab/kg body weight

levels developed in tested groups injected with the drug didn't exceed 1.3. The death in lab animals injected with trastuzumab could be attributed to the drug cardiotoxicity effect as evidenced by the occurrence of death in all animals injected with high concentration of the drug ( $370 \mathrm{mg}$ of trastuzumab/kg body weight). The concentration used was five folds higher than human equivalence dose. This guided us to lower the dose used in our experiments.

\section{In vitro detection of anti-trastuzumab antibody levels in patient's serum samples Using ACE assay}

Before Trastuzumab treatment course Any antitrastuzumab Ab levels developed in patient's serum before starting the trastuzumab treatment course was determined. The results of serum samples from 18 patients subjected to analysis revealed that only 3 serum samples showed anti-trastuzumab Ab titers between 0.7-0.8 while the rest samples showed no detected anti-trastuzumab Ab. However in this study these low levels $(<1)$ of antitrastuzumab $\mathrm{Ab}$ titers were considered as artifacts.

At a single point during Trastuzumab treatment course The anti-trastuzumab Ab levels developed in serum samples of 46 patients were determined within the trastuzumab treatment course and samples were divided according to the number of doses administered before blood sample withdrawal. The results of tested serum samples are shown in Table 2. The results revealed that 30 samples showed no detected antitrastuzumab $\mathrm{Ab}$ while the remaining 16 samples showed variable levels of anti-trastuzumab $\mathrm{Ab}$ titers ranging from $1.07-8.18$.
The results of serum samples from the 46 patients shown in Table 2 were further represented using boxand-whisker diagram (Fig. 2). In such plot method, data entry has to be divided into five quartiles; minimum, lower, median, upper and maximum value. In the plot, one box is constructed extending from the lower quartile to the upper one. The box length represents the difference between the two quartiles, the upper and the lower ones. The median of the total dataset appears in the middle of the box as vertical line. In both directions of the boxplot, two lines can be drawn extending outside the box to give two additional vertical lines, one vertical line close to the upper quartile (termed upper whisker) and another one close to the lower quartile (termed lower whisker). This diagram shows that the median of all results was calculated to be 2.52 with upper quartile 4.12 and lower quartile 0.99 within the box. The interquartile range from the box was extended to represent minimum value 0 (serum samples showing no detectable anti-trastuzumab $\mathrm{Ab}$ ) and maximum value of 8.18 (the largest value determined in serum samples)

\section{At 2 different points during Trastuzumab treatment} course The anti-trastuzumab Ab levels developed in serum samples of 32 patients were determined at 2 different points during trastuzumab treatment course and the results are shown in Table 3. The results revealed that at the 1st assay point 16 out of 32 tested samples showed variable levels of anti-trastuzumab $\mathrm{Ab}$ ranging from 1.13-4.64, while at the 2nd assay point only 9 out of 32 tested samples showed variable levels of antitrastuzumab $\mathrm{Ab}$ ranging from 1.01-2.4.

The result of serum samples from the 32 patients shown in Table 3 were further represented using boxand-whisker diagram (Fig. 3). This diagram shows that 
Table 2 Anti-trastuzumab Ab levels developed in 46 patien's serum samples and determined at a single point during trastuzumab treatment course

\begin{tabular}{|c|c|c|c|c|}
\hline \multirow{2}{*}{$\begin{array}{l}\text { Administered } \\
\text { doses before } \\
\text { blood sample } \\
\text { withdrawal }\end{array}$} & \multirow{2}{*}{$\begin{array}{l}\text { Sample } \\
\text { Code }\end{array}$} & \multicolumn{2}{|l|}{ Titer } & \multirow{2}{*}{$\begin{array}{l}\text { *Percentage } \\
\text { of positive } \\
\text { samples }\end{array}$} \\
\hline & & Value & $\pm \mathrm{SD}$ & \\
\hline \multirow[t]{6}{*}{1} & $\mathrm{~T} 1-19$ & $\mathrm{ND}$ & & $33.33 \%$ \\
\hline & $\mathrm{T} 1-20$ & 4.61 & 0.62 & \\
\hline & $\mathrm{T} 1-21$ & 0.49 & 0.04 & \\
\hline & $\mathrm{T} 1-22$ & ND & & \\
\hline & $\mathrm{T} 1-23$ & 3.64 & 0.02 & \\
\hline & $\mathrm{T} 1-24$ & ND & & \\
\hline \multirow[t]{3}{*}{2} & $\mathrm{~T} 1-25$ & 0.73 & 0.04 & $66.67 \%$ \\
\hline & $\mathrm{T} 1-26$ & 2.86 & 0.04 & \\
\hline & $\mathrm{T} 1-27$ & 6.65 & 1.78 & \\
\hline \multirow[t]{4}{*}{3} & $\mathrm{~T} 1-28$ & ND & & $75 \%$ \\
\hline & T1-29 & 1.27 & 0.02 & \\
\hline & $\mathrm{T} 1-30$ & 2.52 & 0.05 & \\
\hline & $\mathrm{T} 1-31$ & 5.31 & 0.07 & \\
\hline \multirow[t]{4}{*}{4} & $\mathrm{~T} 1-32$ & 0.89 & 0.04 & $50 \%$ \\
\hline & $\mathrm{T} 1-33$ & ND & & \\
\hline & $\mathrm{T} 1-34$ & 7.78 & 0.24 & \\
\hline & $\mathrm{T} 1-35$ & 8.18 & 0.60 & \\
\hline 5 & $\mathrm{~T} 1-36$ & 0.56 & 0.03 & NVC \\
\hline 6 & $\mathrm{~T} 1-37$ & ND & & \\
\hline \multirow[t]{2}{*}{7} & $\mathrm{~T} 1-38$ & ND & & \\
\hline & T1-39 & 1.07 & 0.07 & \\
\hline \multirow[t]{6}{*}{8} & $\mathrm{~T} 1-40$ & $N D$ & & $33.33 \%$ \\
\hline & $\mathrm{T} 1-41$ & ND & & \\
\hline & $\mathrm{T} 1-42$ & ND & & \\
\hline & $\mathrm{T} 1-43$ & 2.03 & 0.1 & \\
\hline & $\mathrm{T} 1-44$ & 2.77 & 0.44 & \\
\hline & $\mathrm{T} 1-45$ & ND & & \\
\hline \multirow[t]{4}{*}{10} & $\mathrm{~T} 1-46$ & $N D$ & & $25 \%$ \\
\hline & $\mathrm{T} 1-47$ & ND & & \\
\hline & $\mathrm{T} 1-48$ & ND & & \\
\hline & $\mathrm{T} 1-49$ & 2.9 & 0.001 & \\
\hline \multirow[t]{2}{*}{12} & $\mathrm{~T} 1-50$ & ND & & NVC \\
\hline & $\mathrm{T} 1-51$ & ND & & \\
\hline \multirow[t]{2}{*}{13} & $\mathrm{~T} 1-52$ & $N D$ & & \\
\hline & $\mathrm{T} 1-53$ & ND & & \\
\hline \multirow[t]{6}{*}{14} & $\mathrm{~T} 1-54$ & 3.36 & 0.06 & $16.67 \%$ \\
\hline & $\mathrm{T} 1-55$ & ND & & \\
\hline & $\mathrm{T} 1-56$ & ND & & \\
\hline & $\mathrm{T} 1-57$ & 0.98 & 0.08 & \\
\hline & $\mathrm{T} 1-58$ & ND & & \\
\hline & $\mathrm{T} 1-59$ & ND & & \\
\hline
\end{tabular}


Table 2 Anti-trastuzumab Ab levels developed in 46 patien's serum samples and determined at a single point during trastuzumab treatment course (Continued)

\begin{tabular}{|c|c|c|c|c|}
\hline \multirow{2}{*}{$\begin{array}{l}\text { Administered } \\
\text { doses before } \\
\text { blood sample } \\
\text { withdrawal }\end{array}$} & \multirow{2}{*}{$\begin{array}{l}\text { Sample } \\
\text { Code }\end{array}$} & \multicolumn{2}{|l|}{ Titer } & \multirow{2}{*}{$\begin{array}{l}\text { *Percentage } \\
\text { of positive } \\
\text { samples }\end{array}$} \\
\hline & & Value & $\pm S D$ & \\
\hline \multirow[t]{2}{*}{15} & T1-60 & 2.14 & 0.07 & NVC \\
\hline & $\mathrm{T} 1-61$ & 0.99 & 0.03 & \\
\hline \multirow[t]{2}{*}{16} & $\mathrm{~T} 1-62$ & ND & & \\
\hline & T1-63 & ND & & \\
\hline 17 & $\mathrm{~T} 1-64$ & 5.77 & 0.27 & \\
\hline
\end{tabular}

*Percentage of positive samples was calculated from samples that gave titers $\geq 1$ relative to the number of tested samples of patients administered the same number of doses

ND no detected antibodies, NVC not valid for calculations

in the 1st assay point the median of all results was calculated to be 1.94 with upper quartile 2.7and lower quartile 1.33 within the box. The interquartile range from the box was extended to represent minimum value 0 (serum samples showing no detectable anti-trastuzumab $\mathrm{Ab}$ ) and maximum value of 4.64 (the largest value determined in serum samples). While in the 2 nd assay point the diagram shows that the median of all results was calculated to be 1.35 with upper quartile 1.67 and lower quartile 1.06 within the box. The interquartile range from the box was extended to represent minimum value 0 (serum samples showing no detectable antitrastuzumab $\mathrm{Ab}$ ) and maximum value of 2.4 (the largest value determined in serum samples).

After trastuzumab treatment course The antitrastuzumab Ab levels developed in patient's serum samples were determined after the 17 doses of trastuzumab treatment course (the standard treatment schedule is 1 dose every 3 weeks, however there was a deviation from this schedule and the treatment course was completed over a period 12-18 months). The results of serum samples from the 5 patients subjected to analysis are shown in Table 4. However, the patient of the serum sample coded T3-99 didn't complete the 17 doses of trastuzumab treatment course as she didn't respond clinically to treatment. She only received 2 doses of trastuzumab.

ACE assay validation parameters were calculated using IBM SPSS Statistics Data Editor. To determine assay cutoff point (the level of response above which a sample is defined as positive), all ADA titers are represented in a ROC curve as shown in Fig. 4. From sensitivity and specificity of the titer data shown in Fig. 4, the calculated cutoff point was found to be 1 .

\section{Using MTT cytotoxicity assay}

MTT cytotoxicity assay was used to determine neutralizing activity of anti-trastuzumab $\mathrm{Ab}$ in single patient serum sample coded T3-99 which showed the highest $\mathrm{Ab}$ titer by ACE assay. The cytotoxicity of trastuzumab (Herceptin) on MCF-7 was determined first. Figure 5 shows the cytotoxicity profile of trastuzumab on the tested cells from which it can be demonstrated that $250 \mu \mathrm{g} /$ well trastuzumab produced about $30 \%$ cytotoxicity. The $250 \mu \mathrm{g} /$ well trastuzumab dose was mixed with three dilutions of sample patient serum T3-99 in

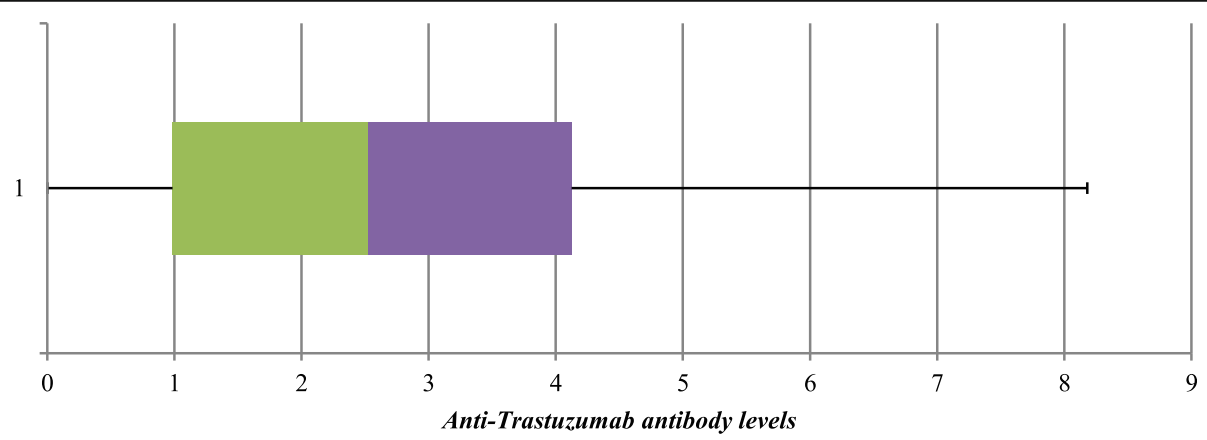

Fig. 2 Box and whisker diagram for anti-trastuzumab Ab levels developed in 46 patient's serum samples and determined at a single point during trastuzumab treatment course 
Table 3 Anti-trastuzumab Ab levels developed in 32 patien's serum samples and determined at two different points during trastuzumab treatment course

\begin{tabular}{|c|c|c|c|c|c|c|c|c|}
\hline \multirow{2}{*}{$\begin{array}{l}\text { Sample } \\
\text { code }\end{array}$} & \multirow{2}{*}{$\begin{array}{l}\text { No. of administered doses } \\
\text { before } 1 \mathrm{st} \text { assay point }\end{array}$} & \multicolumn{3}{|c|}{ 1st assay point titer } & \multirow{2}{*}{$\begin{array}{l}\text { No. of administered doses } \\
\text { before } 2 \text { nd assay point }\end{array}$} & \multicolumn{3}{|c|}{ 2nd assay point titer } \\
\hline & & Value & $\begin{array}{l} \pm \\
\text { SD }\end{array}$ & $\begin{array}{l}\text { *Percentage of } \\
\text { positive samples }\end{array}$ & & Value & $\pm \mathrm{SD}$ & $\begin{array}{l}\text { **Percentage of } \\
\text { positive samples }\end{array}$ \\
\hline $\mathrm{T} 2-65$ & 1 & 1.36 & 0.01 & $71.43 \%$ & 12 & ND & & $28.13 \%$ \\
\hline \multirow[t]{2}{*}{ T2-66 } & & 1.94 & 0.02 & & 10 & 1.65 & 0.04 & \\
\hline & & & & & 12 & ND & & \\
\hline T2-67 & & ND & & & 10 & ND & & \\
\hline T2-68 & & 1.61 & 0.02 & & 16 & ND & & \\
\hline T2-69 & & ND & & & 10 & ND & & \\
\hline $\mathrm{T} 2-70$ & & 3.1 & 0.01 & & 7 & ND & & \\
\hline $\mathrm{T} 2-71$ & & 2.77 & 0.05 & & 10 & 1.37 & 0.07 & \\
\hline $\mathrm{T} 2-72$ & 2 & ND & & $80 \%$ & 12 & ND & & \\
\hline $\mathrm{T} 2-73$ & & 1.78 & 0.06 & & 14 & 2.25 & 0.01 & \\
\hline $\mathrm{T} 2-74$ & & 1.56 & 0.09 & & 12 & 1.02 & 0.03 & \\
\hline $\mathrm{T} 2-75$ & & 3.07 & 0.05 & & 14 & 2.4 & 0.04 & \\
\hline T2-76 & & 2.93 & 0.1 & & 10 & 1.01 & 0.04 & \\
\hline \multirow[t]{2}{*}{ T2-77 } & 3 & ND & & $0 \%$ & 8 & ND & & \\
\hline & & & & & 15 & ND & & \\
\hline $\mathrm{T} 2-78$ & & ND & & & 17 & ND & & \\
\hline T2-79 & & ND & & & 15 & ND & & \\
\hline $\mathrm{T} 2-80$ & 4 & ND & & $33.33 \%$ & 6 & ND & & \\
\hline T2-81 & & 2.24 & 0.02 & & 14 & ND & & \\
\hline T2-82 & & 0.85 & 0.1 & & 12 & ND & & \\
\hline T2-83 & & ND & & & 16 & ND & & \\
\hline $\mathrm{T} 2-84$ & & ND & & & 14 & ND & & \\
\hline T2-85 & & 1.13 & 0.01 & & 14 & 1.33 & 0.001 & \\
\hline T2-86 & 6 & ND & & $25 \%$ & 13 & ND & & \\
\hline T2-87 & & ND & & & 15 & ND & & \\
\hline T2-88 & & 2.43 & 0.01 & & 13 & ND & & \\
\hline T2-89 & & ND & & & 14 & ND & & \\
\hline T2-90 & 7 & 2.63 & 0.16 & $67 \%$ & 13 & 1.18 & 0.03 & \\
\hline T2-91 & & ND & & & 16 & ND & & \\
\hline T2-92 & & 4.64 & 0.03 & & 17 & 1.67 & 0.05 & \\
\hline T2-93 & 8 & ND & & $50 \%$ & 17 & ND & & \\
\hline T2-94 & & 0.85 & 0.01 & & 15 & ND & & \\
\hline T2-95 & & 1.29 & 0.08 & & 16 & ND & & \\
\hline T2-96 & & 1.95 & 0.06 & & 16 & ND & & \\
\hline
\end{tabular}

*Percentage of positive samples was calculated from samples that gave titers $\geq 1$ relative to the number of tested samples of patients administered the same number of doses

**Percentage of positive samples was calculated from samples that gave titers $\geq 1$ relative to the total number of samples in 2 nd assay point

presence of MCF-7 cells using three different regimens as described in materials and methods. Results of cytotoxicity assay in Table 5 showed that the neutralization of trastuzumab activity could be observed in regimen 1 (the drug and serum preparations were added simultaneously to MCF-7 cell line) and regimen 2 (the serum preparations were added to MCF-7 cell line one hour before drug addition).

IBM SPSS Statistics Data Editor was used to validate the results obtained by MTT cytotoxicity assay. The 


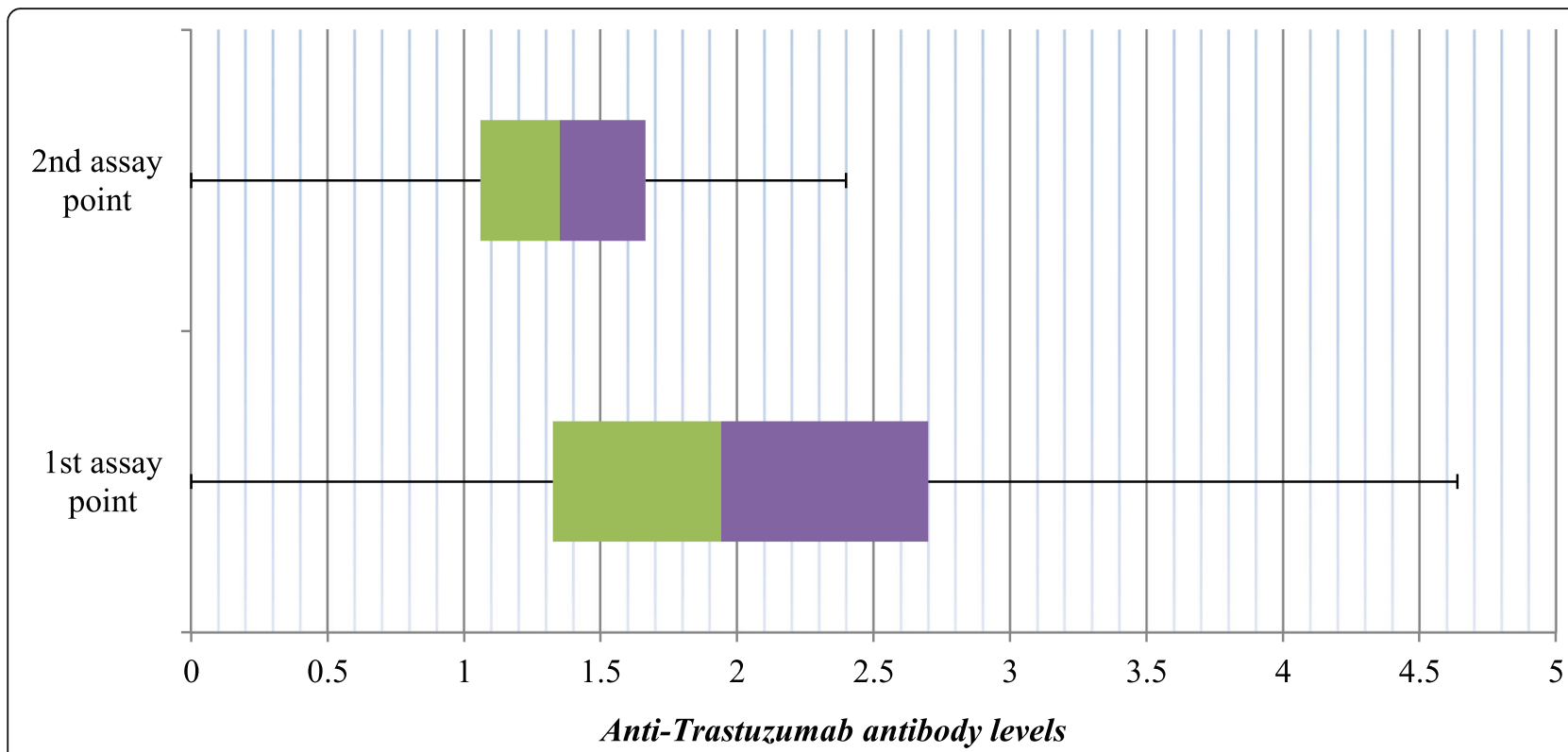

Fig. 3 Box and whisker diagram for anti-trastuzumab Ab levels developed in serum samples of 32 patients and determined at two different points during Trastuzumab treatment course

cytotoxicity profile of trastuzumab against MCF-7 cells was presented as a scatter plot shown in Fig. 6. The figure shows the correlations with $\mathrm{R}^{2}$ of 0.97 and regressions with the equation shown below.

$$
\mathrm{Y}=6.53+0.13 * \mathrm{X}
$$

Where $\mathrm{Y}$ is the cytotoxicity percentage and $\mathrm{X}$ is trastuzumab concentration $(\mu \mathrm{g} /$ well)

\section{Discussion}

Trastuzumab therapeutic monoclonal $\mathrm{Ab}$ is dosed at high levels and has relatively long half-life resulting in significant blood levels for extended periods of time. The presence of high concentration of circulating drug could make detection of anti-trastuzumab Ab very difficult, so in the present study blood samples collection

Table 4 Anti-trastuzumab Ab levels developed in patien's serum samples after trastuzumab treatment course

\begin{tabular}{llll}
\hline $\begin{array}{l}\text { Sample } \\
\text { code }\end{array}$ & Titer & 土SD & $\begin{array}{l}\text { *Elapsed } \\
\text { time } \\
\text { (months) }\end{array}$ \\
\hline Value & ND & 4 \\
T3-98 & ND & & 11 \\
T3-99 & 103.63 & 5.58 & 22 \\
T3-100 & 7.13 & 0.1395 & 9 \\
T3-101 & ND & & 7 \\
\hline
\end{tabular}

*Elapsed time: time passed after last dose of treatment course till sample withdrawal was done after washouts of the drug and in vitro detection of anti-trastuzumab antibody levels in patient's serum samples was performed using ACE assay method. ACE assay method is sensitive enough to detect low levels of ADA as well as it involves the dissociation of ADA-drug complexes with acid treatment, this enable determination of total ADA developed in patient's serum.

In vitro detection of anti-trastuzumab $\mathrm{Ab}$ levels in serum samples of 18 patients before trastuzumab treatment course showed no detectable anti-trastuzumab Ab in all patients except in three samples which showed low level $(<1)$ of anti-trastuzumab Ab titers. These ADA may be due to non-specific reactions during the assay process and/or non-recognized pre exposure to the drug or other relevant drugs that induced cross reactions with the target drug. In vitro detection of anti-trastuzumab Ab levels in serum samples of 46 patients at a single point during trastuzumab treatment course revealed that 16 (34.8\%) samples gave variable levels of antitrastuzumab Ab titers ranging from 1.07-8.18. Comparing the results of tested serum samples at various administered doses $(1,2,3,4,8,10$ and 14, those represented by $\geq$ three serum samples), the results showed that there is a relationship between the number of administered doses and the percentage of positive samples up to 3 administered doses. Higher administered doses showed a dose dependent reduction in percentage of positive samples. This could be due to the tolerance developed by the body after the initial administered doses. In vitro detection of anti-trastuzumab $\mathrm{Ab}$ 


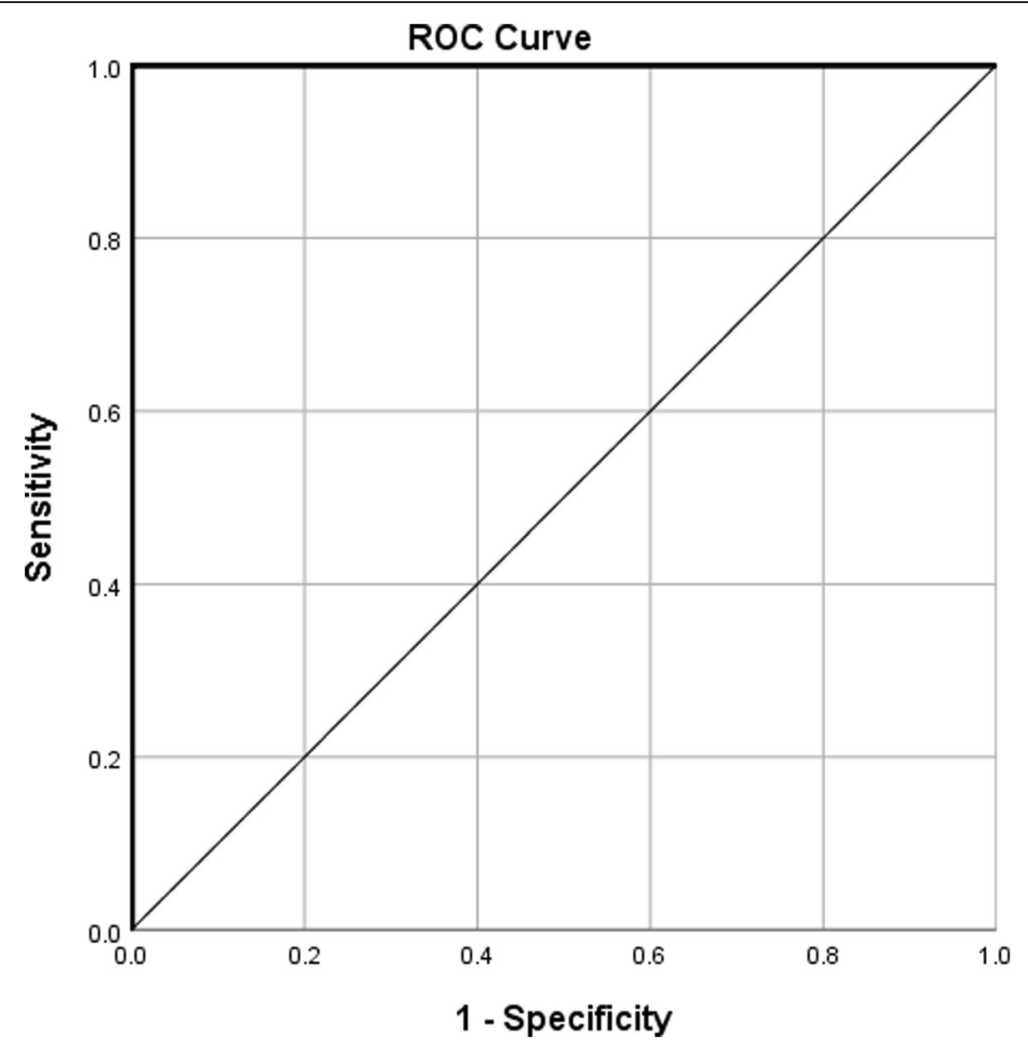

Fig. 4 ROC curve for ACE assay analysis results. The area under the curve (AUC) represents the test result variable: ADA titer values from ACE assay of all serum samples, larger values of the test result variable indicate stronger evidence for a positive actual state

levels in serum samples of 32 patients at 2 different assay points during trastuzumab treatment course showed that in the 1st assay point $50 \%$ of samples showed variable levels of anti-trastuzumab $\mathrm{Ab}$ ranging from 1.13-4.64 (Table 3). While in the 2nd assay point the percentage decreased to be only $28.13 \%$ of samples that showed variable levels of anti-trastuzumab Ab ranging from 1.01-2.4. From the results it appears that the percentages of patients showed anti-trastuzumab $\mathrm{Ab}$ obviously decreased in the 2nd assay point and also the maximum value determined in the tested samples was lower than that obtained in the 1st assay point (2.4 in the 2 nd assay point versus 4.64 in the 1 st assay point). Additionally, most samples showed either marked decrease or no detectable Ab levels when they assessed in the 2nd assay point (Table 3). In case of trastuzumab, ADA developed in most patients seems to be transient as they decreased progressively along the treatment

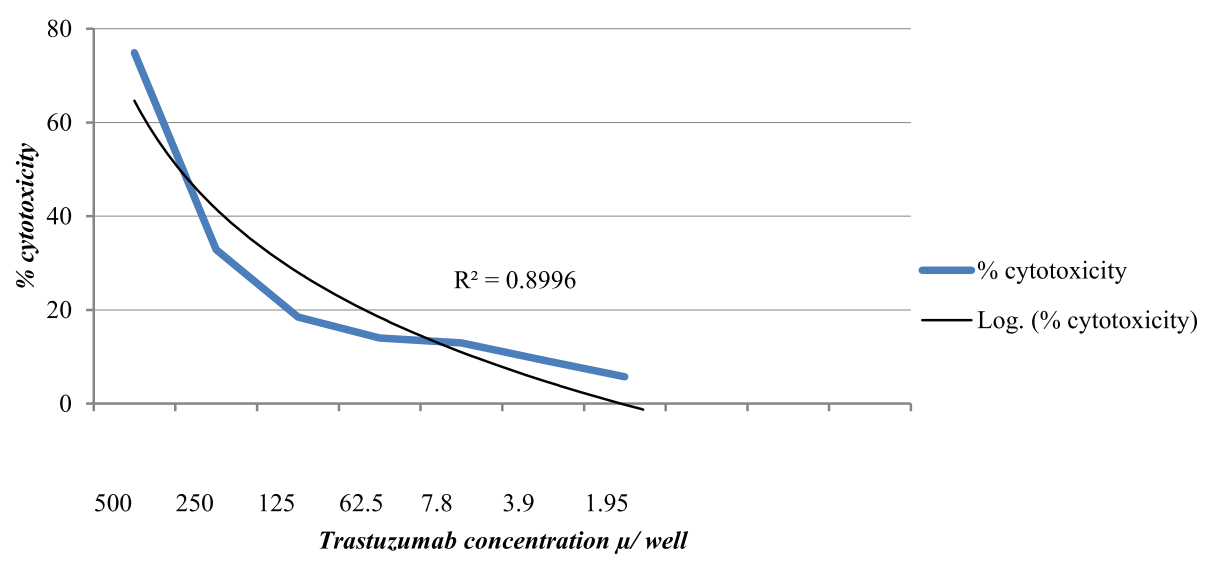

Fig. 5 Cytotoxicity profile of trastuzumab against MCF-7 cell line as determined by MTT cytotoxicity assay 
Table 5 MTT cytotoxicity assay of neutralizing activity of antitrastuzumab Ab developed in patient's serum using MCF-7 cell line

\begin{tabular}{|c|c|c|c|c|c|c|c|c|}
\hline \multirow{3}{*}{$\begin{array}{l}\text { Serum } \\
\text { dilutions }\end{array}$} & \multicolumn{8}{|c|}{$\%$ Cytotoxicity } \\
\hline & \multicolumn{2}{|c|}{ Control } & \multicolumn{2}{|c|}{ 1st Regimen } & \multicolumn{2}{|c|}{ 2nd Regimen } & \multicolumn{2}{|c|}{ 3rd Regimen } \\
\hline & Value & $\pm \mathrm{SD}$ & Value & $\pm \mathrm{SD}$ & Value & $\pm \mathrm{SD}$ & Value & $\pm \mathrm{SD}$ \\
\hline 0 & 36.89 & 0.08 & 36.89 & 0.08 & 36.89 & 0.08 & 36.89 & 0.08 \\
\hline $1: 20$ & & & 49.19 & 0.12 & 29.88 & 0.05 & 34.19 & 0.04 \\
\hline $1: 100$ & & & 12.12 & 0.27 & 1.49 & 0.12 & 25.98 & 0.10 \\
\hline $1: 200$ & & & 0.76 & 0.15 & 13.71 & 0.02 & 50.22 & 0.08 \\
\hline
\end{tabular}

Control: Drug alone added to MCF-7 cell line

1 st Regimen: Both drug and serum dilutions were added simultaneously to MCF-7 cell line

2nd Regimen: The serum dilutions were added to MCF-7 cell line $1 \mathrm{~h}$ before addition of the drug

3rd Regimen: Both drug and serum dilutions were mixed at equal volumes and left at room temperature for $1 \mathrm{~h}$ before their addition to MCF-7 cell line

course. This observation was supported by the clinical outcomes recorded for the patients under study since they showed positive response to the treatment with the drug and no adverse events were detected during trastuzumab treatment course. The results obtained in our study are in agreement with those reported by Bian et al. [11], who stated that ADA can be either persistent or transient, of which the latter kind is of less concern as transient ADA rarely impact clinical outcomes and adverse events. Immunogenicity detected after complete trastuzumab treatment course revealed that only 2 patient's serum samples gave significant levels of antitrastuzumab Ab (Table 4). The serum sample coded T3-99 (withdrawn 22 months after last trastuzumab dose) and T3-100 (withdrawn 9 months after last trastuzumab dose) showed persistent levels of antitrastuzumab Ab. However serum sample T3-100 was of lower levels of anti-trastuzumab Ab titer (7.13) compared to the anti-trastuzumab Ab level obtained in case of serum sample T3-99 (103.33). Clinically, the patient of sample coded T3-100 could complete 17 doses of trastuzumab treatment course without negative impact in clinical outcome. On the other hand patient with serum sample coded T3-99 experienced negative clinical outcomes that ended by the stop of trastuzumab administration after the 2nd dose. It can be summed up that among 101 patients, serum analysis for detection of antitrastuzumab $\mathrm{Ab}$, only one patient (1\%) showed high level of persistent anti-trastuzumab $\mathrm{Ab}$. The clinical unresponsiveness of that patient (serum sample T3-99) could be attributed to the development of high titer of anti-trastuzumab $\mathrm{Ab}$ as detected by analysis of her serum (Table 4). Trastuzumab as humanized mAb (produced by replacing most mouse sequence derived amino acids for human sequences, only the complementarity determining regions (CDRs) of the variable (v) regions of mouse sequence origin remain) has less ability to trigger immunogenic responses compared with murine (purified derived mouse $\mathrm{Ab}$ ) and chimeric $\mathrm{Ab}$ (replacing murine

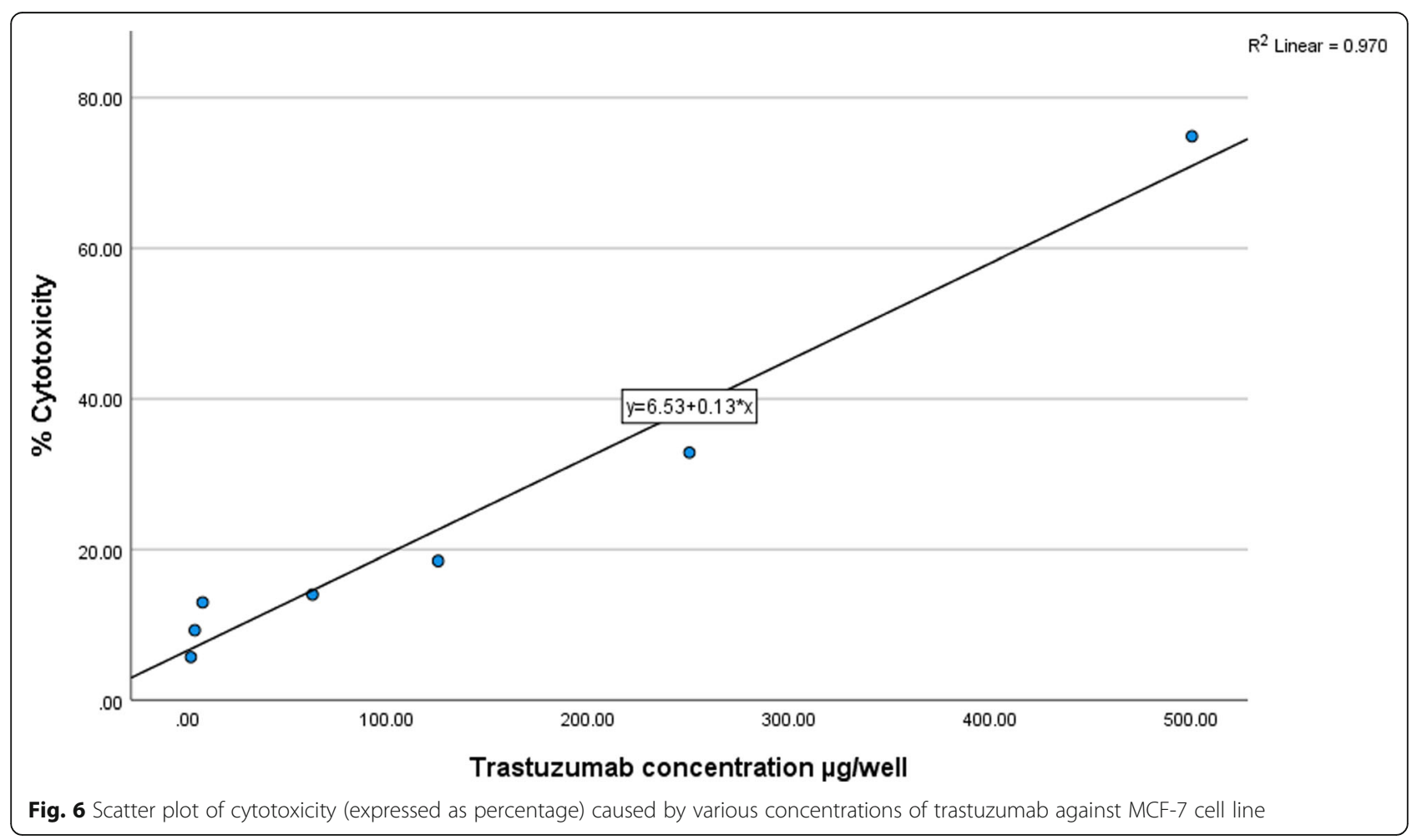


constant regions with human constant regions). As a result, in humanized $\mathrm{Ab} \mathrm{T}$ cell epitopes were so much reduced and found only in CDRs. Consequently, a likely reduction of the immunogenic potential while retaining full biologic function. This is the way by which immunogenicity of insulin was much reduced by the development human insulin $[29,30]$. This may explain the observed low immunogenicity in this and other studies. However, some humanized and even fully human mAb still carry immunological risks [30, 31].

MTT cytotoxicity assay was used as confirmatory method for the in vitro detection of anti-trastuzumab $\mathrm{Ab}$ levels in patient's serum samples and to determine neutralizing activity of anti-trastuzumab Ab using a single patient serum sample (sample coded T3-99). MCF-7 cell line could respond to a higher concentration of trastuzumab as $250 \mu \mathrm{g}$ that produced about $30 \%$ cytotoxicity, this enabled us to detect the neutralizing activity of the developed $\mathrm{Ab}$. The usage of 3 regimens of loading drug and serum on MCF-7 cell line showed that the neutralization of trastuzumab activity could be observed in regimen 1 (the drug and serum preparations added simultaneously to MCF-7 cell line) and regimen 2 (the serum preparations were added to MCF-7 cell line $1 \mathrm{~h}$ before drug addiction). On the other hand this activity wasn't demonstrated in case of regimen 3 (both drug and serum preparations were mixed and left at room temperature for $1 \mathrm{~h}$ before their addition to MCF-7 cell line). This observation indicates that the mechanism of detected neutralizing activity of anti-trastuzumab $\mathrm{Ab}$ may be due to their effect on cell line rather than on the drug itself. It's known that the degree of immunocomplex formation depends on the relative concentrations of $\mathrm{Ab}$ and drug molecules. As a result interaction between the $\mathrm{Ab}$ and the cell line depends on its degree of association/dissociation from its immunocomplex. Aize Kijlstra et al., reported that the immunocomplex dissociates by dilutions [32].

In vivo immunogenicity testing of trastuzumab in lab animals revealed absence of relationships between drug concentration, Ab titer, treatment period and the number of doses administered in each group of tested animals. However the low immunogenicity of trastuzumab detected in lab animals was comparable to the antitrastuzumab Ab levels measured in clinical serum samples. This gives an evidence of low immunogenicity of trastuzumab that could support its continuous use as biological therapeutic agent.

\section{Conclusion}

In this study trastuzumab showed results that indicate its low immunogenicity as biological therapeutic agent in pre-clinical and clinical studies. As very low percentage of patients can show high titer of anti-trastuzumab antibodies that is impacted clinically, it is much recommended to take into consideration detection of immunogenicity of trastuzumab in patients showing any serious adverse events or unresponsiveness to treatment after starting trastuzumab treatment course.

\section{Methods}

The present study was approved by The Institution Review Board (IRB) of National Cancer Institute (NCI) under the IRB No. IRB00004025. This approval was issued according to ICH-GCP guidelines. Signed informed consents were obtained from all patients whom their blood samples and clinical data were used in this study. Additionally, another approval by the Safety and Occupational Health Committee at Faculty of Pharmacy, Cairo University, Cairo, Egypt with serial No. of MI (1481) has certify that this study doesn't affect the health and safety.

All methods involving human participants, human sera and human data were carried out in accordance with Declaration of Helsinki and approved by IRB of NCI. All methods involving animal use were conducted in accordance with Research Ethics Committee (REC) for experimental and clinical studies at Faculty of Pharmacy, Cairo University, Cairo, Egypt which approved the conducted research. All experimental protocols were approved by Faculty of pharmacy, Cairo University, Cairo, Egypt.

\section{Animals}

Male Swiss albino mice (Vacsera animal house, Egypt.) were used in the in vivo immunogenicity study.

\section{Blood samples and sera}

Blood samples from 101 patients diagnosed with breast cancer (stages I-IV as classified and categorized according to TNM [tumor, node, and metastasis] stage classification) were obtained from NCI, Cairo, Egypt. In some cases more than one blood sample were obtained from the same patient. The blood samples were provided in Serum Separating Tubes (SST, KEMICO vacutainer, Z serum Clot Activator with Gel) [33]. Sera were prepared from all collected blood samples by allowing the blood containing tubes (approximately $5 \mathrm{ml}$ aliquots) to clot for a minimum of $60 \mathrm{~min}$ in a vertical position at room temperature following by centrifugation at $3000 \times \mathrm{g}$ for $10 \mathrm{~min}$. The supernatants were separately aliquoted into 2-3 portions and stored at $-40^{\circ} \mathrm{C}$ until use. Blood samples were collected from patients who their tumor biopsies were HER2 positive and under treatment with trastuzumab. Clinical data for all patients included in the study were reviewed and any AEs was recorded. Nearly all patients (100 out of 101) showed no observed AEs during the treatment course except infusion related 
reactions (IRRs) like fever, redness and swelling that were observed in few patients, and it was not known if these reactions related to trastuzumab or any other combined drugs. Only one female out of 101 included patients, her clinical data showed unresponsiveness for treatment with trastuzumab and the treatment was stopped after the 2nd dose.

\section{Cell line and its maintenance}

Human breast cancer cell line MCF-7 (ATCC ${ }^{\bullet}$ HTB$22^{\mathrm{rax}}$ ) was obtained from Vacsera, Cairo, Egypt. The cell line was routinely cultured in $75-\mathrm{ml}$ tissue culture flasks (Nunc Thermofisher Scientific) in RPMI 1640 medium supplemented with $10 \%$ heat inactivated fetal bovine serum, $2 \mathrm{mM}$ non-essential amino acids, $2 \mathrm{mM}$ sodium pyruvate, $100 \mathrm{units} / \mathrm{ml}$ penicillin and $100 \mu \mathrm{g} / \mathrm{ml}$ streptomycin (all from Sigma, USA), the cultured cells were incubated in $\mathrm{CO}_{2}$ incubator at $37^{\circ} \mathrm{C}$ and $5 \% \mathrm{CO} 2$.

\section{Chemicals and reagents}

The chemicals used in the present study included: $\mathrm{NaCO}_{3}$ and $\mathrm{NaCl}$ (El Nasr pharmaceutical chemicals Co., Egypt), $\mathrm{NaHCO}_{3}$ (Biowest Co., USA), Tris/Trizma base and Tween 80 (Sigma, USA), Orthophosphoric acid 85\% (Sigma-Aldrich, GmbH, Germany) and Acetic Acid, glacial extra pure (Sham lab, Syria). The reagents used in the present study included: $\mathrm{BupH}$ carbonate-bicarbonate buffer, $0.01 \mathrm{M}$ Tris-Buffered Saline (TBS), TBST (TBS containing $0.05 \%$ Tween 80 ). Therapeutic monoclonal antibody trastuzumab (Tmab) was supplied by Roche Diagnostics (GmbH, Germany), Streptavidin poly -HRP was obtained from Pierce (Pierce Biotechnology, Rockford, IL, N200) and Biotin-Trastuzumab Conjugate (B-Tmab) was prepared by labeling of therapeutic humanized monoclonal antibody Trastuzumab (Tmab) using EZ-Link Sulfo-NHS-LC-Biotinylation Kits (Pierce, $21,435)$ according to manufacturer's instructions.

\section{In vivo immunogenicity testing of trastuzumab in lab animals}

Four groups (one control group and three groups for different concentrations of trastuzumab 14.8, 74 and $148 \mathrm{mg} / \mathrm{kg}$ ) each contain 7 mice were assigned. Animals were 6-7 weeks old and weighed between 18 and $22 \mathrm{~g}$ at the initiation of dosing.

\section{Dose preparation and administration for animal experiments}

Three dose levels of $14.8,74$ and $148 \mathrm{mg} / \mathrm{kg}$ [the middle dose of $74 \mathrm{mg} / \mathrm{kg}$ were chosen depending on mouse equivalence dose to human maintenance dose of $6 \mathrm{mg} /$ $\mathrm{kg}$. The animal equivalent dose (AED) was calculated from data adapted from FDA draft guidelines with slight modifications. Thereafter, a 5 -fold lower dose equal to
$14.8 \mathrm{mg} / \mathrm{kg}$ and a 2 -fold higher dose equal to $148 \mathrm{mg} / \mathrm{kg}$ ] were determined and a dose volume of $0.3 \mathrm{ml} / \mathrm{mouse}$ was assigned. Trastuzumab as a lyophilized commercial product, was first reconstituted in sterile water for injection according to the product label $(440 \mathrm{mg} / 20 \mathrm{ml})$ and then further dilution in $0.9 \%$ sodium chloride (normal saline) was carried out. The control group was administered normal saline and each of the other 3 groups received one of the three concentrations of Trastuzumab $(14.8,74$ or $148 \mathrm{mg} / \mathrm{kg})$ by slow intravenous (IV) injection into the tail vein every 21 days for 84 days. The doses were prepared under sterile conditions. For serum, peripheral pooled blood from each group was collected in approximately $3 \mathrm{ml}$ aliquot after 14 days from injection. Sera were prepared from all collected blood samples for tested groups by allowing the blood contained in tubes to clot for a minimum of $30 \mathrm{~min}$ while the tubes in a vertical position at room temperature following by centrifugation at $3000 \times \mathrm{g}$ for $10 \mathrm{~min}$. The supernatants were separately aliquoted and stored at $-40{ }^{\circ} \mathrm{C}$ until use [34].

\section{In vitro detection of anti-trastuzumab antibody $(\mathrm{Ab})$ in serum samples}

This was carried out using either Affinity Capture Elution (ACE) assay or MTT cytotoxicity assay against MCF-7 cell line.

ACE assay was used for detecting anti-trastuzumab Ab in all serum samples recovered from patients and tested animals.

\section{ACE assay procedures}

ELISA plates (Corning Incorporated, 96 Well EIA/RIA Plates, corning, NY 14831, USA) were coated with therapeutic humanized monoclonal antibody (Tmab) at a concentration of $5 \mu \mathrm{g} / \mathrm{ml}$ in $\mathrm{BupH}$ carbonate-bicarbonate buffer by adding $100 \mu \mathrm{l}$ per well and incubating overnight at $4{ }^{\circ} \mathrm{C}$. Samples were diluted $1: 10$ in TBS. Aliquots $(100 \mu \mathrm{l}$ each) were acidified with $50 \mu \mathrm{l} 300 \mathrm{mM}$ acetic acid and incubated at room temperature for 5 min. Tmab coated plates were washed three times with TBST and $50 \mu \mathrm{l} 1 \mathrm{M}$ Tris $\mathrm{pH} 9.5$ were added to each well. Acid-treated samples $(100 \mu \mathrm{l}$ aliquots) were added to the buffered coated wells and the plates were incubated overnight at $4{ }^{\circ} \mathrm{C}$. The following day, plates were washed three times with TBST followed by elution of bound ADA by addition of $65 \mu \mathrm{l} 300 \mathrm{mM}$ acetic acid for $5 \mathrm{~min}$ at room temperature. New Plates were then loaded with $50 \mu \mathrm{l}$ aliquots of $1 \mathrm{M}$ Tris $\mathrm{pH} 9.5$ buffer. Aliquots $(50 \mu \mathrm{l}$ each) of the acid eluate were transferred to the plates containing the buffer solution followed by incubation for $1 \mathrm{~h}$ at room temperature to allow binding of eluted ADA to the wells. Plates were then washed three times with TBST and blocked with casein buffer 
(1\% in PBS) for $1 \mathrm{~h}$ at room temperature. After washing three times with TBST, $100 \mu \mathrm{l}$ aliquots B-Tmab conjugate were added and incubated at room temperature for $1 \mathrm{~h}$ to allow binding to plate bound ADA. Plates were then washed three times with TBST and $100 \mu$ aliquots SA-HRP solution were added to the wells and the plates were incubated for $30 \mathrm{~min}$ at room temperature. After that, the plates were washed three times with TBST and $100 \mu \mathrm{l}$ aliquots of $3,3^{\prime}, 5,5^{\prime}$ tetramethylbenzidine (TMB) substrate (Ortho-Clinical Diagnostics Pencoed, UK) were added to the wells and incubated for $30 \mathrm{~min}$ at room temperature. Color development was stopped by addition of $100 \mu \mathrm{l}$ aliquots of $2 \mathrm{M}$ phosphoric acid, and the plates were read at $450 \mathrm{~nm}$ in a Biotek ELx800 plate reader [13].

\section{MTT cytotoxicity assay}

This assay was conducted using MCF-7 cell line and used for detecting anti-trastuzumab $\mathrm{Ab}$ in one human serum sample that showed the highest anti-trastuzumab $\mathrm{Ab}$ titer in ACE assay. The cells were treated in triplicate with trastuzumab (Herceptin $440 \mathrm{mg} / 20 \mathrm{ml}$ ) over a period of $72 \mathrm{~h}$ to determine the resistance and sensitivity of the breast cancer cell line to the monoclonal antibodies [35-37]. Cells were seeded at a density of $5 \times 10^{3}$ cells $/ \mathrm{ml}$ in volumes of $100 \mu \mathrm{l}$ medium into 96-well plates and incubated in $\mathrm{CO}_{2}$ incubator at $37^{\circ} \mathrm{C}$ and $5 \% \mathrm{CO}_{2}$ for $24 \mathrm{~h}$. Aliquots $(100 \mu \mathrm{l}$ each) of the trastuzumab dilutions were added to the cells in triplicates at concentrations of $500,250,125,62.5,31.25,15.6,7.8,3.9,1.95$, $0.975,0.49$ and $0.245 \mu \mathrm{g}$ per well to determine the optimal concentration for the cytotoxicity assay. Following incubation of cells for $72 \mathrm{~h}$ in $\mathrm{CO}_{2}$ incubator at $37^{\circ} \mathrm{C}$ and $5 \% \mathrm{CO}_{2}$, a $50 \mu \mathrm{l}$ aliquots of MTT solution were added to each well and the plates were re-incubated for further $4 \mathrm{~h}$ followed by adding a $50 \mu \mathrm{l}$ aliquot of DMSO to each well. Absorbance was measured immediately in a plate reader at $570 \mathrm{~nm}$. Cytotoxicity was recorded as a percentage of that obtained for the control untreated cells (100\%) [35].

MTT cytotoxicity assay was also conducted with trastuzumab (Herceptin $440 \mathrm{mg} / 20 \mathrm{ml}$ ) at the concentration giving 30\% cytotoxicity ( $250 \mu \mathrm{g} /$ well) in presence of 3 dilutions of the serum sample preparation containing antitrastuzumab antibodies [1:20, 1:100 and 1:200] in triplicate. Cells suspension $\left(5 \times 10^{3}\right.$ cells $\left./ \mathrm{ml}\right)$ was seeded at $100 \mu \mathrm{l}$ aliquots into 96-well plates and incubated in $\mathrm{CO}_{2}$ incubator at $37^{\circ} \mathrm{C}$ and $5 \% \mathrm{CO}_{2}$ for $24 \mathrm{~h}$. The neutralizing activity of anti-trastuzumab $\mathrm{Ab}$ was tested at 3 different regimens: (i) 1st regimen, equal volumes $(100 \mu \mathrm{l}$ each) of the drug and serum preparations were added simultaneously to MCF-7 cell line; (ii) 2nd regimen, serum sample preparations ( $50 \mu \mathrm{l}$ aliquots) were added to MCF-7 cell line $1 \mathrm{~h}$ before addition of the drug
(50 $\mu \mathrm{l} /$ well); (iii) 3rd regimen, both drug and serum sample preparations were mixed at equal volumes and left at room temperature for $1 \mathrm{~h}$ before the addition of their mixture to MCF-7 cell line at $100 \mu \mathrm{l}$ per well. Following incubation of cells for $72 \mathrm{~h}$ in $\mathrm{CO}_{2}$ incubator at $37^{\circ} \mathrm{C}$ and $5 \% \mathrm{CO} 2$, a $50 \mu \mathrm{l}$ aliquots of MTT solution were added to the wells and the plates were re-incubated for further $4 \mathrm{~h}$ followed by adding a $50 \mu \mathrm{l}$ aliquot of DMSO to each well. Absorbance was measured immediately in a plate reader at $570 \mathrm{~nm}$. Cytotoxicity was recorded as a percentage of that obtained for the control untreated cells $(100 \%)$.

\section{Abbreviations}

mAb: monoclonal antibody; HER2: human epidermal growth factor receptor2; Ab: antibody; ACE assay: An Affinity Capture Elution assay; ADAs: anti-drug antibodies; ATAs: anti-therapeutic antibodies; IG: immunogenic; nADAs: neutralizing ADAs; NABs: neutralizing antibodies:

PK: pharmacokinetics; PD: pharmacodynamics; SC/IV: subcutaneous/ intravenous; CDRs: complementarity determining regions; AEs: adverse events; IRRs: infusion related reactions; Tmab: Trastuzumab; IRB: The Institution Review Board; NCl: National Cancer Institute; ICH-

GCP: International Council for Harmonisation- Good Clinical Practice; AED: animal equivalent dose; IV: intravenous; TBS: Tris-Buffered Saline; BTmab: Biotin-Trastuzumab Conjugate; SA-HRP: Streptavidin poly-HRP; TMB: tetramethylbenzidine

\section{Acknowledgements \\ The authors are thankful to all participants in this study and institutions (NORCB, NCl, VACSERA applied research lab and VACSERA animal house) for providing the research facilities, patient samples and animal housing facilities to conduct this study}

Authors' information (optional)

N/A as described in title page.

\section{Authors' contributions}

LAK, conducted the lab work, data presentation and wrote the draft of the manuscript; $A A G$, research idea conceptualization, supervised the work; MMA, research idea conceptualization, data analysis, manuscript writing and revision; $\mathrm{HHZ}$, research idea conceptualization, manuscript revision. The author(s) read and approved the final manuscript.

\section{Funding}

This study was not funded by any agency.

\section{Availability of data and materials}

The datasets used and/or analyzed during the current study are included in the manuscript. All data are available upon request through the corresponding author of the manuscript.

\section{Ethics approval and consent to participate}

The present study was approved by The Institution Review Board (IRB) of National Cancer Institute (NCI) under the IRB No. IRB00004025. This approval was issued according to ICH-GCP guidelines. Signed informed consents were obtained from all patients whom their blood samples and clinical data were used in this study. Additionally another approval by the Safety and Occupational Health Committee at Faculty of Pharmacy, Cairo University, Cairo, Egypt with serial No. of MI (1481) has certify that this study doesn't affect the health and safety. All methods involving animals use were carried out in compliance with the ARRIVE guidelines and approved by the Research Ethics Committee (REC) for experimental and clinical studies at Faculty of Pharmacy, Cairo University, Cairo, Egypt.

\section{Consent for publication}

N/A. 


\section{Competing interests}

The authors declare that they have no competing interests.

\begin{abstract}
Author details
${ }^{1}$ National Organization for Research and Control of Biologicals (NORCB), 51 Wezaret El Zeraa St, El-Agouza-Giza, Dokki, Egyptian Drug Authority, P.O Box: 354, Dokki, Egypt. ${ }^{2}$ Department of Oncology, National Cancer Institute, Cairo University, Kornish El-Nile - Fom El- Khaleg, Cairo 11796, Egypt. ${ }^{3}$ Department of Microbiology and Immunology, Faculty of Pharmacy, Ain Shams University, African union organization Street, Abbassia, Cairo 11566, Egypt. ${ }^{4}$ Faculty of Pharmacy, King Salman International University, Ras-Sedr, South Sinai, Egypt. ${ }^{5}$ Department of Microbiology and Immunology, Faculty of Pharmacy, Cairo University, Kasr El-Aini St, Cairo 11562, Egypt.
\end{abstract}

\section{Received: 5 November 2020 Accepted: 3 February 2021}

\section{Published online: 19 February 2021}

\section{References}

1. Pham NB, Meng WS. Protein aggregation and immunogenicity of biotherapeutics. Int J Pharm. 2020;585:1 19523. https://doi.org/10.1016/j.jpha rm.2020.119523.

2. Sperinde G, Montgomery D, Mytych DT. Clinical immunogenicity risk assessment for a fusion protein. AAPS J. 2020;22:1-6. https://doi.org/10.12 08/s12248-020-00447-y.

3. Krishna M. Product-related factors and immunogenicity of biotherapeutics. J Pharm Innov. 2020;15:219-31. https://doi.org/10.1007/s12247-019-09423-2.

4. Kierzek AM, Hickling TP, Figueroa I, Kalvass JC, Nijsen M, Mohan K, et al. A quantitative systems pharmacology consortium approach to managing immunogenicity of therapeutic proteins. CPT Pharmacometrics Syst Pharmacol. 2019:8:773-6. https://doi.org/10.1002/psp4.12465.

5. Yogurtcu ON, Sauna ZE, McGill JR, Tegenge MA, Yang H. TCPro: an in Silico risk assessment tool for biotherapeutic protein immunogenicity. AAPS J. 2019;21. https://doi.org/10.1208/s12248-019-0368-0.

6. Hamuro L, Kijanka G, Kinderman F, Kropshofer H, Bu D xiu, Zepeda M, et al. Perspectives on subcutaneous route of administration as an immunogenicity risk factor for therapeutic proteins. J Pharm Sci. 2017;106: 2946-54. https://doi.org/10.1016/j.xphs.2017.05.030.

7. Pivot X, Bondarenko I, Nowecki Z, Dvorkin M, Trishkina E, Ahn JH, et al. Phase III, randomized, double-blind study comparing the efficacy, safety, and immunogenicity of SB3 (trastuzumab biosimilar) and reference trastuzumab in patients treated with neoadjuvant therapy for human epidermal growth factor receptor 2-positive early. J Clin Oncol. 2018;36:96874. https://doi.org/10.1200/JCO.2017.74.0126.

8. Dingman R, Balu-lyer SV. Immunogenicity of protein pharmaceuticals. J Pharm Sci. 2019;108:1637-54. https://doi.org/10.1016/j.xphs.2018.12.014.

9. Pimentel FF, Morgan G, Tiezzi DG, de Andrade JM. Development of new formulations of biologics: expectations, immunogenicity, and safety for subcutaneous Trastuzumab. Pharmaceut Med. 2018;32:319-25. https://doi. org/10.1007/s40290-018-0247-5.

10. Ponce R, Abad L, Amaravadi L, Gelzleichter T, Gore E, Green J, et al. Immunogenicity of biologically-derived therapeutics: assessment and interpretation of nonclinical safety studies. Regul Toxicol Pharmacol. 2009; 54:164-82. https://doi.org/10.1016/j.yrtph.2009.03.012.

11. Bian S, Ferrante M, Gils A. Validation of a drug-resistant anti-Adalimumab antibody assay to monitor immunogenicity in the presence of high concentrations of Adalimumab. AAPS J. 2017;19:468-74. https://doi.org/1 0.1208/s12248-016-0018-8.

12. Noda-Narita S, Shimomura A, Kawachi A, Sumiyoshi-Okuma H, Sudo K, Shimoi T, et al. Comparison of the efficacy of trastuzumab emtansine between patients with metastatic human epidermal growth factor receptor 2-positive breast cancers previously treated with combination trastuzumab and pertuzumab and with trastuzumab only in Japanese popu. Breast Cancer. 2019;26:492-8. https://doi.org/10.1007/s12282-019-00949-4.

13. Bourdage JS, Cook CA, Farrington DL, Chain JS, Konrad RJ. An affinity capture elution (ACE) assay for detection of anti-drug antibody to monoclonal antibody therapeutics in the presence of high levels of drug. J Immunol Methods. 2007;327:10-7. https://doi.org/10.1016/j.jim.2007.07.004.

14. Vaisman-Mentesh A, Gutierrez-Gonzalez M, DeKosky BJ, Wine Y. The molecular mechanisms that underlie the immune biology of anti-drug antibody formation following treatment with monoclonal antibodies. Front Immunol. 2020;11. https://doi.org/10.3389/fimmu.2020.01951.
15. Bivi N, Swearingen CA, Shockley TE, Sloan JH, Pottanat TG, Carter QL, et al. Development and validation of a novel immunogenicity assay to detect antidrug and anti-PEG antibodies simultaneously with high sensitivity. J Immunol Methods. 2020;486:112856. https://doi.org/10.1016/j.jim.2020.112856.

16. Kovalova N, Knierman MD, Brown-Augsburger PL, Wroblewski VJ, Chlewicki LK. Correlation between antidrug antibodies, pre-existing antidrug reactivity, and immunogenetics (MHC class II alleles) in cynomolgus macaque. Immunogenetics. 2019;71:605-15. https://doi.org/10.1007/s00251-019-01136-7.

17. Xiang Y, Parng C, Olson K, Seletskaia E, Gorovits B, Jani D, et al. Neutralizing antibody assay development with high drug and target tolerance to support clinical development of an anti-TFPI therapeutic monoclonal antibody. AAPS J. 2019;21:1-10. https://doi.org/10.1208/s12248-019-0320-3.

18. Chen YQ, Pottanat TG, Carter QL, Troutt JS, Konrad RJ, Sloan JH. Affinity capture elution bridging assay: a novel immunoassay format for detection of anti-therapeutic protein antibodies. J Immunol Methods. 2016:431:45-51. https://doi.org/10.1016/j.jim.2016.02.008.

19. Hegg R, Pienkowski T, Chen S, Staroslawska E, Falcon S, Kovalenko N, et al. 273P - Immunogenicity of Trastuzumab Intravenous and Subcutaneous Formulations in the Phase III Hannah Study. Ann Oncol. 2012;23(ix103). https://doi.org/10.1016/s0923-7534(20)32835-0.

20. Padron IM, Garcia JG, D_ıaz RR, Lenza IC, Nicolas FG. Anti-drug antibodies anti-trastuzumab in the treatment of breast cancer. J Oncol Pharm Pract 2020;0:1-3. doi:https://doi.org/10.1177/1078155220953873.

21. Triguero MC, Yi J-H, Dere R, Zhihua JQ, Lei C, Li Y, et al. Immunogenicity assays for antibody-drug conjugates: case study with ado-trastuzumab emtansine. Bioanalysis. 2013;9:1007-23.

22. Xavier P, Hii CSJ, Mclendon K, Feyaerts P, Felicia A, Demarchi MF, et al. A phase III trial to compare the efficacy, safety, pharmacokinetics and immunogenicity of HD201 to trastuzumab in HER2+ early breast cancer patients (TROIKA). Ann Oncol. 2020;31:S307. https://doi.org/10.1016/j.a nnonc.2020.08.288.

23. Kayser V, Chennamsetty N, Voynov V, Helk B, Trout BL, Kayser V, et al. Conformational stability and aggregation of therapeutic monoclonal antibodies studied with ANS and Thioflavin T binding. MAbs. 2011:4:408-11. https://doi.org/10.4161/mabs.3.4.15677.

24. Dhillon S. ABP 980: A Trastuzumab Biosimilar. BioDrugs. 2018;32:511-4. https://doi.org/10.1007/s40259-018-0305-2.

25. Lamb YN. SB3 (Ontruzant ${ }^{\oplus}$ ): A Trastuzumab Biosimilar. BioDrugs. 2018;32: 293-6. https://doi.org/10.1007/s40259-018-0282-5.

26. Pivot $\mathrm{X}$, Bondarenko I, Nowecki Z, Dvorkin M, Trishkina E, Ahn JH, et al. A phase III study comparing SB3 (a proposed trastuzumab biosimilar) and trastuzumab reference product in HER2-positive early breast cancer treated with neoadjuvant-adjuvant treatment: final safety, immunogenicity and survival results. Eur J Cancer. 2018;93:19-27. https://doi.org/10.1016/j.ejca.2 018.01.072.

27. Lammers PE, Dank M, Masetti R, Abbas R, Hilton F, Coppola J, et al. Neoadjuvant PF-05280014 (a potential trastuzumab biosimilar) versus trastuzumab for operable HER2+ breast cancer. Br J Cancer. 2018;119:26673. https://doi.org/10.1038/s41416-018-0147-1.

28. Wang J, Niu S, Dong W, Wei L, Ou L, Zhang T, et al. A randomized phase I clinical trial comparing the pharmacokinetic, safety, and immunogenicity of potential biosimilar recombinant human HER2 monoclonal antibody for injection and trastuzumab in healthy Chinese adults. Expert Opin Investig Drugs. 2020;29:755-62. https://doi.org/10.1080/13543784.2020.1770226.

29. Onda M. Reducing the Immunogenicity of Protein Therapeutics 2009:131-139.

30. Harding FA, Stickler MM, Razo J, Dubridge R, Harding FA, Stickler MM, et al. The immunogenicity of humanized and fully human antibodies Residual immunogenicity resides in the CDR regions The immunogenicity of humanized and fully human antibodies Residual immunogenicity resides in the CDR regions. 2010;0862. https://doi.org/10.4161/mabs.2.3.11641.

31. Qu Z, Griffiths GL, Wegener WA, Chang CH, Govindan SV, Horak ID, et al. Development of humanized antibodies as cancer therapeutics. Methods. 2005;36:84-95. https://doi.org/10.1016/j.ymeth.2005.01.008.

32. Kijlstra A, Knutson DW, VDL A, AVE L. Characteristics of soluble immune complexes prepared from oligovalent DNP conjugates and Anti-DNP Antibodies. J Immunol Methods. 1977;17:236-77. https://doi.org/10.1017/ CBO9781107415324.004.

33. Karakoyun I, Arslan FD, Onur S, Ozturk YK, Parildar H, et al. Comparison of 30 Biochemical Analytes in 3 Different Blood Collection Tubes. Türk Klinik Biyokimya Derg. 2020;18:61-9. 
34. Hurst S, Ryan AM, Ng CK, McNally JM, Lorello LG, Finch GL, et al. Comparative nonclinical assessments of the proposed biosimilar PF05280014 and trastuzumab (Herceptin`). BioDrugs. 2014;28:451-9. https:// doi.org/10.1007/s40259-014-0103-4.

35. Patra S, Young V, Llewellyn L, Senapati JN, Mathew J. BRAF, KRAS and PIK3CA mutation and sensitivity to Trastuzumab in breast cancer cell line model. Asian Pacific J Cancer Prev 2017;18:2209-13. doi:https://doi.org/10.22 034/APJCP.2017.18.8.2209.

36. Scaltriti M, Verma C, Guzman M, Jimenez J, Parra JL, Pedersen K, et al. Lapatinib, a HER2 tyrosine kinase inhibitor, induces stabilization and accumulation of HER2 and potentiates trastuzumab-dependent cell cytotoxicity. Oncogene. 2009;28:803-14. https://doi.org/10.1038/onc.2 008.432 .

37. Abo-zeid MA, Abo-elfadl MT, Gamal-Eldeen AM. Trastuzumab augments apoptotic cell death of MCF-7 and MDA-MB-231 breast Cancer cell lines. J Pharm Sci Res. 2019;11:324-30.

\section{Publisher's Note}

Springer Nature remains neutral with regard to jurisdictional claims in published maps and institutional affiliations.

Ready to submit your research? Choose BMC and benefit from:

- fast, convenient online submission

- thorough peer review by experienced researchers in your field

- rapid publication on acceptance

- support for research data, including large and complex data types

- gold Open Access which fosters wider collaboration and increased citations

- maximum visibility for your research: over $100 \mathrm{M}$ website views per year

At BMC, research is always in progress.

Learn more biomedcentral.com/submissions 